УДК 636.2.09:616.153.284 «321»

(C) 2017

\author{
Кравченко С. О., Канівець Н. С., кандидати ветеринарних наук, \\ Романенко С. В., аспірант \\ (науковий керівник - кандидат ветеринарних наук С. О. Кравченко)
}

Полтавська державна аграрна академія

\title{
ПРОФІЛАКТИКА КЕТОЗУ ВИСОКОПРОДУКТИВНИХ КОРІВ У ВЕСНЯНИЙ ПЕРІОД
}

\section{Рецензент - кандидат ветеринарних наук О. В. Кручиненко}

\begin{abstract}
У даній статті представлено результати дослідження впливу кормової добавки «BergaFat F - 100» на окремі біохімічні показники крові високопродуктивних корів. Показано кількість хворих на кетоз корів y весняний період (34,1\% новотільних корів) і середню кількість кетонових тіл у крові - 2,64士0,14 (2,44,6) ммоль/л. 3'ясовано, щзо в разі застосовування «BergaFat $F-100 »$ кількість хворих корів на кетоз зменшилась на 36,7 \%, а середня кількість кетонових тіл у крові хворих тварин становила 1,37士0,06 (1,11,8) ммоль/л, шчо у 1,9 раз $(p<0,001)$ менше за попередній рік. Наведено порівняльну оцінку біохімічних показників сироватки крові корів. У випадку додавання «BergaFat F - 100» до основного раціону досліджені біохімічні показники наближаються до референтної норми.
\end{abstract}

Ключові слова: корова, кетоз, сироватка крові, біохімічні показники, дефіиит енергії.

Постановка проблеми. Збільшення виробництва молока $\epsilon$ ризиковим для здоров'я корів i передбачає високі вимоги до годівлі, утримання та догляду за тваринами. Це в загалом годівля у другу половину сухостою та в перший триместр лактації після отелення, що в подальшому забезпечує правильний обмін речовин та підготовку до наступної лактації. В цей критичний період, недостатня годівля, зокрема дефіцит енергії та стрес можуть бути причиною подальших порушень обміну речовин та захворювання на кетоз, що призводить до зменшення надоїв, вгодованості, порушення відтворної функції, та передчасної вибраковки корів [6, 2].

Аналіз основних досліджень і публікацій, у яких започатковано розв'язання проблеми. Одним зі шляхів збереження поголів'я та отримання від нього високої продуктивності є використання в годівлі компонентів спеціального призначення та спрямованої дії. До таких компонентів, зокрема, належать захищені жири для збагачення енергією раціону годівлі корів [7].

Високопродуктивні корови особливо вимогливі до повноцінності годівлі та забезпеченості енергією в сухостійний період та в перші 90-100 днів лактації. Кількість отриманої енергії з кормом в сухостійний період дуже важлива. Так, якщо в кінці лактації та початку сухостійного періоду необхідно оптимізувати надходження енергії для формування правильної кондиції тіла тварини, то в другій половині сухостою необхідно іiі збільшити в раціоні (через фізіологічне зниження апетиту) [7]. Це позитивно впливає на адаптацію мікрофлори та слизової оболонки рубця для засвоєння великої кількості кормів в післяродовий період. За останніми опублікованими дослідженнями, збільшення енергії в раціоні сухостійних корів в останні три тижні перед отеленням веде до збільшення ваги новонародженого теляти та сприяє кращому імунному захисту [6].

Отже, у перші 100 днів лактації високопродуктивних корів особливо гостро стоїть проблема енергетичного забезпечення раціону. Вирішення цього питання має особливу специфіку, що обумовлена будовою системи травлення у жуйних тварин - тісною взаємодією мікрофлори рубця і організму корови. Ці, об'єднані природою, «організми» вимагають індивідуального підходу в забезпеченні поживними речовинами специфічно їх потребам та цілям, які необхідно досягти від тварини.

Перший триместр лактації у корів $\epsilon$ основоположними не тільки для поточної лактації, а й для всієї економіки і прибутковості виробництва молока. У цей період рівень забезпечення молочних корів енергією $є$ одним з головних факторів, що визначають не тільки їх продуктивність, але i показники нормального відтворення: запліднюваність, регулярність статевих циклів, тривалість сервіс - періоду та інше. При цьому вони можуть легко змінюватися під впливом як недостатньої, так і надмірної годівлі [8].

Якщо з кормом не можуть бути повністю задоволені всі потреби в поживних речовинах для утворення молока у високопродуктивних корів, для утворення молока в цей період в значних кількостях використовуються ліпіди жирових депо і білки м'язових тканин, накопичені органі- 


\section{ВЕТЕРИНАРНА МЕДИЦИНА}

змом тварин у другій половині лактації і особливо в сухостійний період (А. А. Алієв, 1997) [1]. Різка мобілізація внутрішніх резервів із жирових накопичень призводить до підвищеного навантаження на печінку, в результаті чого без застосування профілактичних заходів розвивається синдром «жирової печінки» $[5,2]$, що призводить до кетозу, спаду продуктивності і нерідко до смерті чи вибраковки корови в перші 40-60 днів після отелення. Якщо клінічна картина у тварин не яскраво виражена, то корова сильно втрачає у вазі, що відзначається на ії продуктивності та відтворенні. Причому у корів 3 великими запасами жиру в тілі ці проблеми в перші 90-100 днів лактації проявляються частіше як в паліативній, так і клінічній формах.

Отже, хоча питанню кетозу високопродуктивних корів присвячена значна кількість публікацій, подальше дослідження цього питання $є$ актуальним.

Метою наших досліджень є порівняти кількість хворих на кетоз корів в умовах господарства у весняний період 2016 та 2017 років, концентрацію кетонових тіл та біохімічні показники сироватки крові корів.

Матеріали і методи дослідження. Дослідження проводили на базі ТОВ «Білагро» (Полтавська область, Великобагачанський район, село Колосівка, молочно-товарна ферма №1). У роботі були задіяні корови другої лактації з продуктивністю за 2016 рік 8845 кг на дійну і 7543 кг молока на фуражну. Проводили порівняння концентрації кетонових тіл у крові новотільних корів, що отелилися впродовж весняного періоду 2016 та 2017 років. Клінічні дослідження проводили за загальноприйнятими методами [4, 3]. Кров відбирали на шостий день після розтелення, $з$ підхвостової вени, після чого за допомогою глюкометра «Optium Xceed» та тестсмужок «Free Style Optimum Я-ketone» [2] визначали концентрацію кетонових тіл у крові. Концентрацію кетонових тіл у крові не більше 1,0 ммоль/л приймали за референтну норму [2]. Сироватку крові відправляли до лабораторії «BIOSAFETY CENTR» Науково-дослідного центру біобезпеки та екологічного контролю ресурсів АПК Дніпропетровського державного аграрно-економічного уні- верситету для біохімічного дослідження. Із біохімічних показників брали до уваги вміст загального білка, альбуміни, глобуліни, активність АсАТ, АлАТ, концентрацію глюкози, сечовини, креатинін, лужна фосфатаза, кальцій, неорганічний фосфор. У 2017 році коровам $з$ другої половини сухостійного періоду і до 90-100 днів лактації до раціону додавали «BergaFat F - 100» у вигляді порошку. Даний препарат, розроблений фірмою «Berg + Schmidt» (Німеччина), містить ліпідів 99\%, неперетравного в рубці жиру - $93 \%$, пальмітинової кислоти - не менше $80 \%$, стеаринової кислоти не більше 5 \%. Препарат починали додавати згідно 3 рекомендованими дозами, зазначених виробником: внутрішньо разом із кормом, 240 г на голову для сухостійних корів, далі по 200 г на голову до 30 дня лактації і по 260 г на голову до 100 днів лактації. Після розтелення корів досліджували за схемою, аналогічною 2016 року.

Результати досліджень. Захворюваність корів на кетоз після розтелення у весняний період 2016 та 2017 років наведено у таблиці 1.

3 даної таблиці бачимо, що за 2016 в весняний період кількість хворих корів на кетоз була значною - 53 голови (34,1\% новотільних корів) і середня кількість кетонових тіл у крові становила 2,64士0,14 (2,4-4,6) ммоль/л. Проте, у 2017 році, в разі застосовування «BergaFat F - 100» кількість хворих на кетоз корів є меншою на 36,7 \% 18 голів, а середня кількість кетонових тіл у хворих становить $1,37 \pm 0,06(1,1-1,8)$ ммоль/л, що у 1,9 раз менше за попередній рік $(\mathrm{p}<0,001)$.

Отже, застосування «BergaFat $\mathrm{F}-100 »$ у peкомендованих дозах забезпечує зменшення кількості захворювань на кетоз у корів, а також сприяє зменшенню концентрації кетонів у крові хворих новотільних корів.

Отримані результати підтверджуються позитивною динамікою біохімічних показників крові (таблиця 2). На даній таблиці бачимо, що біохімічні показники різняться у 2016-2017 рр. Так, із застосуванням препарату «BergaFat F-100» в 2017 році біохімічні показники сироватки крові наблизились або прийшли у відповідність фізіологічній нормі $[4,3]$.

\section{1. Захворюваність корів на кетоз у весняний період 2016 та 2017 рр.}

\begin{tabular}{|c|c|c|c|c|c|}
\hline Рік & \multirow{2}{*}{$\begin{array}{c}\text { Кількість розте- } \\
\text { лених корів }\end{array}$} & $\begin{array}{c}\text { Кількість хворих } \\
\text { на кето3 корів }\end{array}$ & $\begin{array}{c}\text { \% від загальної } \\
\text { кількості розте- } \\
\text { лених корів }\end{array}$ & \multicolumn{2}{|c|}{$\begin{array}{c}\text { Середня кількість кетонових тіл } \\
\text { у крові хворих корів, ммоль/л }\end{array}$} \\
\cline { 4 - 6 } & 152 голів & 53 & 34,1 & $2,4-4,6$ & $2,64 \pm 0,14$ \\
\hline 2016 & 144 голів & 18 & 12,5 & $1,1-1,8$ & $1,37 \pm 0,06 * * *$ \\
\hline
\end{tabular}

Примітка: *** $-\mathrm{p}<0,001$, порівняно із 2016 роком. 
ВЕТЕРИНАРНА МЕДИЦИНА

2. Біохімічні показники крові корів у весняний період 2016-2017 рр.

\begin{tabular}{|c|c|c|c|c|c|}
\hline \multirow{2}{*}{ Показники } & \multicolumn{2}{|c|}{ Результати за 2016 p. $(\mathrm{n}=11)$} & \multicolumn{2}{|c|}{ Результати за 2017 p. $(\mathrm{n}=10)$} & \multirow{2}{*}{$\begin{array}{l}\text { Референтна } \\
\text { норма }[4,3]\end{array}$} \\
\hline & Lim & $\mathrm{M} \pm \mathrm{m}$ & Lim & $\mathrm{M} \pm \mathrm{m}$ & \\
\hline Загальний білок, г/л & $65-93$ & $79,72 \pm 2,53$ & $60-76$ & $69,6 \pm 1,33^{*}$ & $72-86$ \\
\hline Альбуміни, г/л & $38-45$ & $41,6 \pm 0,63$ & $37-46$ & $40,5 \pm 0,89$ & $38-50$ \\
\hline Глобуліни, г/л & $23-50$ & $38,09 \pm 2,54$ & $20-39$ & $29,1 \pm 1,82 *$ & $30-35$ \\
\hline Сечовина, ммоль/л & $4,45-7,48$ & $5,54 \pm 0,28$ & $1,9-5,5$ & $3,62 \pm 0,35 * * *$ & $3,5-6,0$ \\
\hline AcAT, Од/л & $72-218$ & $114,09 \pm 11,45$ & $52-108$ & $81,8 \pm 5,56^{*}$ & $10-50$ \\
\hline АлАТ, Од/л & $10-32$ & $24,72 \pm 1,94$ & $14-23$ & $19,2 \pm 0,85^{*}$ & $10-40$ \\
\hline Глюкоза, ммоль/л & $1,25-2,96$ & $2,26 \pm 0,13$ & $3,2-5,4$ & $3,9 \pm 0,17 * * *$ & $2,5-3,3$ \\
\hline Креатинін, мкмоль/л & $53-161$ & $112,7 \pm 8,94$ & $115-164$ & $138,0 \pm 6,00^{*}$ & $45-140$ \\
\hline Лужна фосфатаза, Од/л & $41-228$ & $85,9 \pm 15,5$ & $66-151,7$ & $104,7 \pm 7,5$ & $220-150$ \\
\hline Кальцій, ммоль/л & $2,01-2,99$ & $2,78 \pm 0,08$ & $2,6-3$ & $2,75 \pm 0,03$ & $2,25-3,0$ \\
\hline $\begin{array}{l}\text { Неорганічний фосфор, } \\
\text { ммоль/л }\end{array}$ & $1,3-1,9$ & $1,62 \pm 0,06$ & $1,7-2,6$ & $2,31 \pm 0,08 * * *$ & $1,45-2,1$ \\
\hline
\end{tabular}

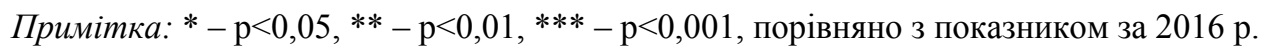

Одержані дані обробили статистично в програмі Excel, визначаючи середню арифметичну (M), статистичну помилку середньої арифметичної (m), вірогідність різниці між середніми арифметичними двох варіаційних рядів за t-критерієм Стьюдента $(\mathrm{p}<)$. Дослідження сироватки крові корів показали, що значні зміни показників реєстрували у 2016 р. Так, рівень загального білка та глобулінів був вищий відповідно на 14,5 та $30,9 \%(\mathrm{p}<0,05)$ у порівнянні 3 показниками 2017 року, а рівень глюкози був занадто низьким $(\mathrm{p}<0,001)$.

Це свідчить про надмірне протеїнове живлення, що спричинює посилене утворення аміаку в передшлунках, який нейтралізується в печінці і перетворюється на сечовину. Таку тенденцію підтверджує і зниження рівня сечовини на 36,2 $\%(\mathrm{p}<0,001)$ у 2017 році.

Активність АлАТ та АсАТ $є$ меншою $(\mathrm{p}<0,05)$ в 2017 році у порівнянні з 2016 роком. Зниження

\section{БІБЛІОГРАФІЯ}

1. Алиев А. А. Обмен липидов / А. А. Алиев, В. Димов. - М. : НИЦ «Инженер», 1997. - С. 161-231.

2. Внутрішні хвороби тварин / [Левченко В. І., Влізло В. В., Кондрахін І. П. та ін.] ; за ред. В. І. Левченка. - Біла Церква, 2015. - Ч. 2. - 610 с.

3. Клінічна діагностика внутрішніх хвороб тварин / [Левченко В. І., Влізло В. В., Кондрахін І. П. та ін.] ; за ред. В. І. Левченка. - Біла Церква, 2004. $608 \mathrm{c}$.

4. Методы ветеринарной клинической лабораторной диагностики: Справочник / под ред. проф. И. П. Кондрахина. - М. : Колос, 2004. - 520 с.

5. Порушення ліпідного обміну у молочних ко- активності трансаміназ у сироватці крові свідчить про зменшення інтенсивності деструктивних процесів в печінці. Проте, як бачимо з таблиці 2 , величина цих показників не увійшла до референтної норми, отже навантаження на гепатоцити залишається надмірним.

Коливання вмісту креатиніну не виходить за межі норми та свідчить про інтенсифікацію обміну білків. Вищий уміст неорганічного фосфору у крові корів в 2017 році свідчить про порівняно вищу активність обміну речовин у кістковій тканині, що можна визнати позитивним.

Висновок. 3 даних досліджень бачимо, що застосування «BergaFat F - 100» компенсує дефіцит енергії у післяродовий період, що значно зменшує кількість хворих на кетоз корів, рівень кетонових тіл у крові хворих тварин та сприяе нормалізації біохімічних показників крові. Це заощаджує ветеринарні витрати на ліквідацію кетозу у господарстві.

рів, хворих на кетоз / [Сімонов М. Р., Гультяєва О. В., Пилипець А. 3., Влізло В. В.] // Вісник аграрної науки. - 2014. - №1. - С. 24-28.

6. Чумаченко В. Ю. Резистентність тварин і фактори, що впливають на їх стан / В. Ю. Чумаченко // Ветеринарна медицина України. - 1997. - №3. - 23 с.

7. Gluconeogenesis in dairy cows: the secret of making sweet milk from sour dough / [Aschenbach J. R., Kristensen N. B., Donkin S. S. et al.] // IUBMB Life. 2010. - Vol. 62. - №12. - P. 869-877.

8. Feed into Milk. A new applied feeding system for dairy cows / Eq. By C. Tomas // Nottingham University Press. $-2004 .-68$ p. 